J. Clin. Chem. Clin. Biochem.

Vol. 26, 1988, pp. $91-99$

(C) 1988 Walter de Gruyter \& Co. Berlin - New York

\title{
Simultaneous Determination of the Most Abundant Cationic Species in Human Urine by Capillary Isotachophoresis
}

\author{
By P. Pei and D.J. Vonderschmitt \\ Institut für Klinische Chemie, Universitätsspital Zürich, Schweiz
}

(Received May 2/December 9, 1987)

\begin{abstract}
Summary: Analytical isotachophoresis has proved to be an excellent method for separation and quantitative measurement of ionic species in biologic fluids. Isotachophoretic separation of cations in presence of a complex-forming nonionic detergent (e.g. Triton X-100) in $98 \%$ methanol enables simultaneous quantitative determination of ammonium, sodium, potassium, magnesium, and protonated creatinine in urine samples. For calcium determination in urine, lead acetate was used to precipitate anions that form complexes with calcium.
\end{abstract}

The mean deviation from $100 \%$ recovery of ammonium, sodium, potassium, magnesium,calcium and creatinine added to urine samples is $3.1 \%$. The proposed method shows good agreement with chemical (routine) methods.

\section{Introduction}

Quantitative determinations of components in urine samples is of limited value for two main reasons:

1. The concentration of components varies strongly with diuresis. A 24-hour urine collection is therefore necessary, in order to calculate daily excretion. There are, however, many factors in the collection, storage and handling of urine samples which influence the final analytical result.

2. The daily excretion rate is strongly dependent on intake of nutrients and water.

Nevertheless, a number of clinical situations require quantitative urine analysis for adequate patient management. Patients depending on haemodialysis or undergoing an immunosuppressive therapy and patients depending on parenteral nutrition present such situations. Another clinical situation is given by the diagnosis of metabolic disorders leading to urolithiasis. Hesse (1) has estimated normal values for the amount of a series of cations and anions excreted daily in order to estimate the risk for urolithiasis.
Some other indications for urinary electrolyte determinations are given by Eastham (2) and Durborski (3).

Our own experience shows that determination of urinary sodium, potassium, magnesium, calcium and creatinine accounts for about $50 \%$ of all routine chemical urine analyses. Hirst (4) has used a multichannel urine analyser of the continuous flow type for the simultaneous determination of sodium, potassium, calcium, phosphate, creatinine and urea. He has encountered problems with the high dynamic range that is required in urine analysis, as opposed to the analysis of blood serum or plasma.

Isotachophoresis is extremly suitable for the simultaneous determination of either cations or anions. We recently reported a method for the separation and measurement of anionic components (5). While anionic components have also been studied by ionchromatography (6), no alternative method is known for the simultaneous analysis of the cationic components in the same sample or specimen. Several methods of isotachophoretic separations of cation mixtures 
have been proposed $(14,15)$ and most of them have been reviewed by Bocek \& Foret in 1984 (16). However, none of these methods can be used for the simultaneous determination of the most abundant cationic species (e.g. $\mathrm{NH}_{4}^{+}, \mathrm{Na}^{+}, \mathrm{K}^{+}, \mathrm{Mg}^{2+}, \mathrm{Ca}^{2+}$ and creatinine- $\mathrm{H}^{+}$) in human urine. The isotachophoretic procedure offers the big advantage of high dynamic range. From the practical standpoint, it is limited only by the time that can reasonably be spent on an analysis.

\section{Materials and Methods}

Urine samples

The 24-h urine specimens were collected, stored at $4{ }^{\circ} \mathrm{C}$ during the sampling period, and acidified with conc. $\mathrm{HCl}$.

\section{Reagents}

All chemicals used were of analytical grade. Electrolyte systems and other operational, conditions are summarized in table 1.

The separation capillary was occasionally treated overnight with a $0.4 \mathrm{~g} / \mathrm{l}$ aqueous solution of hydroxypropylmethylcellulose (HPMC). This procedure improved the performance by lowering the minimal detectable amount and by sharpening the boundaries between zones.

A reference mixture of seven cations was prepared, containing creatinine and chloride salts of ammonium, caesium, sodium, potassium, mangnesium and calcium respectively. The concentration of each component was $1.0 \mathrm{mmol} / \mathrm{l}$. The standards of calibration for the quantitative determination of these cations in urine were prepared with four different concentrations (3.0$80 \mathrm{mmol} / \mathrm{l}$ ). Caesium chloride with a final concentration of 10 $\mathrm{mmol} / \mathrm{l}$ was used as an internal standard. For calcium determination a precipitating solution containing a mixture of 15 $\mathrm{mmol} / \mathrm{l}$ caesium chloride and $85 \mathrm{mmol} / \mathrm{l}$ lead acetate was used to eliminate interfering anions (e. g. sulphate, phosphate, oxalate) from native urine.

\section{Instruments}

To compare isotachophoretic results with routine methods we used a flame photometer (Model IL 553, Instrumentation Laboratory) for the determination of sodium and potassium, and a polarized Zeeman atomic absorption spectrophotometer (Model 180-80, Hitachi, Ltd. Tokyo, Japan) for the estimation of magnesium and calcium. Ammonium was determined on a Cobas Bio centrifugal analyser. The ammonium assay kit (Procedure No. 170-UV) was purchased from Sigma Diagnostics, St. Louis, MO, USA. For the determination of creatinine Beckman Creatinine Analyser 2 was used.

A Shimadzu IP-2A isotachophoretic analyser, equipped with a potential gradient detector, a UV-detector, a $200 \mathrm{~mm}$ FEP capillary $(0.5 \mathrm{~mm} \mathrm{I}$. D.) and a $40 \mathrm{~mm}$ PTFE capillary $(1.0 \mathrm{~mm}$ I.D.) as the precolum was used for the separation and measurement of the standard and sample solutions. The apparatus was also equipped with a current program. Microliter samples were injected with a Hamilton syringe. The isotachophoretic patterns for these samples were recorded at a chart speed of $4.0 \mathrm{~cm} / \mathrm{min}$. The data processor used was the isotachopac IE1 B (Shimadzu Corporation, Kyoto, Japan), which calculated the intervals between peaks (zone length), potential gradient values and time between two arbitrary potential values.

\section{Procedures}

Human urine or standard solution was routinely diluted to $1 / 3$ of initial concentration with caesium chloride $15 \mathrm{mmol} / \mathrm{l}$ (internal standard) for the simultaneous determination of ammonium, sodium, potassium, magnesium and creatinine to yield a solution containing $10 \mathrm{mmol} / \mathrm{l}$ of $\mathrm{CsCl}$. Without further pretreatment a volume of $1.0 \mu \mathrm{l}$ was injected into the isotachophoretic analyser. For calcium determinations urine samples and standards were diluted $1+2$ with the precipitating solution, vortex-mixed and centrifuged. A $1 \mu l$ aliquot of supernatant fluid was injected. Since ions having different mobilities travel at an identical speed under isotachophoretic condition, a potential gradient corresponding to the mobility is formed in each zone. The potential gradient is inversely proportional to the mobility. For practical reasons it is often converted into P. U. (potential unit) values, which are general qualitative indices. They are calculated using the following equation:

$$
\text { P.U. value }=\left(\mathrm{P}_{\mathrm{X}}-\mathrm{P}_{\mathrm{L}}\right) / .\left(\mathrm{P}_{\mathrm{T}}-\mathrm{P}_{\mathrm{L}}\right) \text {, where }
$$

$P_{X}, P_{L}$ and $P_{T}$ are potential gradient values of sample ion $X$, leading ion and terminating ion, respectively. From the equation follows that $0<$ P. U. $<1$.

\section{Results}

Two different procedures were compared for the dètermination of cations.

Figure 1 shows the isotachopherogram of the cation reference mixture illustrating the characteristic zone hights of seven cationic components. In this procedure (System B, table 1 and 2) the poor separation between $\mathrm{K}^{+}$and $\mathrm{NH}_{4}^{+}$complicated the quantitative determination of the ions in urine samples. The effect of Triton X-100 (System A, table 1 and 2) on the separation of a reference mixture of cations is shown in figure 2. Addition of $8 \mathrm{~g} / 1$ Triton $X-100$ to the leading electrolyte results in decreased potassium mobility (tab. 2) and well separated zones of potassium and ammonium. Figure 2 also shows the UV-absorbances of ammonium and alkali metal complexes.

In table 2 the P. U. values (qualitative index) for some cations obtained in the operational systems are summarized. This proves that alkali metal ions and ammonium ion formed complexes with Triton X-100 in methanol and accordingly changed their mobilities. A typical example of the resulting isotachopherogram of a urine sample is shown in figure 3.

\section{Calibration and quantification}

Calibration curves were established for ammonium, sodium, potassium, magnesium, calcium and creatinine standards dissolved in both water and pooled urine. For each component the ratio of the zone length to the zone length of the internal standard caesium was calculated and this ratio (M/Cs) was plotted against the concentration $(\mathrm{mmol} / \mathrm{l})$ of the component in the standard solution which had been injected. The 


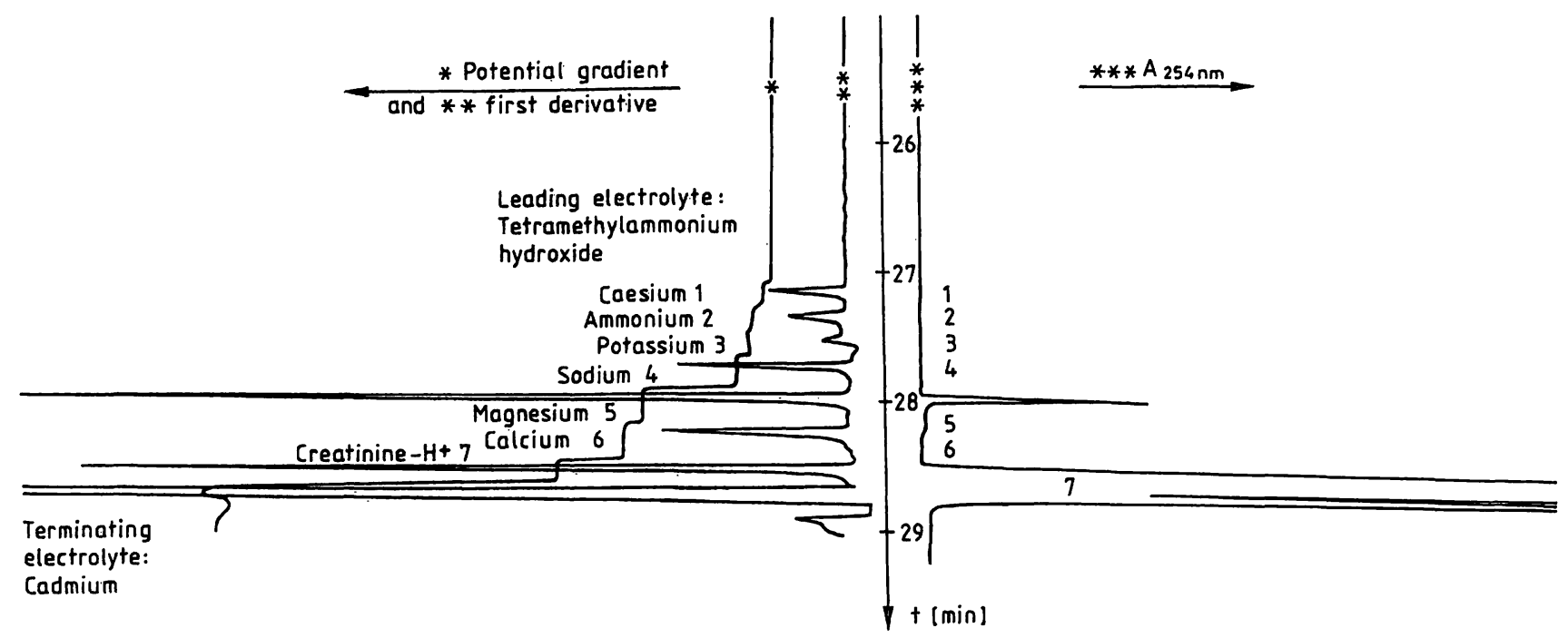

Fig. 1. Isotachopherogram of a standard mixture of seven cations.

volume injected: $5.0 \mu \mathrm{l}(1 \mathrm{mmol} / 1$ of each component) Electrolyte system B was used.

Tab. 1. Operational systems.

\begin{tabular}{lll}
\hline & System A & System B \\
\hline Solvent & $980 \mathrm{ml} / \mathrm{l}$ methanol & $980 \mathrm{ml} / \mathrm{l} \mathrm{methanol}$ \\
Leading electrolyte & $10 \mathrm{mmol} / 1$ tetramethylammonium hydroxide & $10 \mathrm{mmol} / \mathrm{l}$ tetramethylammonium hydroxide \\
& $12 \mathrm{ml} / 1$ acetic acid & $12 \mathrm{ml} / 1$ acetic acid \\
& $0.12 \mathrm{~g} / 1$ hydroxypropylmethylcellulose & $0.12 \mathrm{~g} / 1$ hydroxypropylmethylcellulose \\
& $8 \mathrm{ml} / 1$ Triton X-100 & $\mathrm{pH}=5.57$ \\
Terminating electrolyte & $\mathrm{pH}=5.62$ & $30 \mathrm{mmol} / 1 \mathrm{cadmium} \mathrm{nitrate} \mathrm{pH}=6.0$ \\
Migration current & $30 \mathrm{mmol} / 1 \mathrm{cadmium}$ nitrate $\mathrm{pH}=6.0$ & $200 \mu \mathrm{A}(7 \mathrm{~min}) \rightarrow 75 \mu \mathrm{A}$ \\
Bath temperature & $200 \mu \mathrm{A}(7 \mathrm{~min}) \rightarrow 75 \mu \mathrm{A}$ & $20^{\circ} \mathrm{C}$ \\
\hline
\end{tabular}

Tab. 2. PU values (qualitative index) for some cations obtained in the operational systems.

\begin{tabular}{|c|c|c|c|c|}
\hline \multirow[t]{2}{*}{ Cation } & \multicolumn{2}{|c|}{ System A $(n=13)$} & \multicolumn{2}{|c|}{ System B $(n=7)$} \\
\hline & $\overline{\mathrm{PU}}$ & $\pm S D$ & $\overline{P U}$ & $\pm \mathrm{SD}$ \\
\hline $\begin{array}{l}\text { Tetramethyl- } \\
\text { ammonium }\end{array}$ & 0 & - & 0 & - \\
\hline Caesium & 0.137 & 0.0060 & 0.016 & 0.0008 \\
\hline Ammonium & 0.053 & 0.0027 & 0.038 & 0.0022 \\
\hline Potassium & 0.168 & 0.0103 & 0.044 & 0.0033 \\
\hline Sodium & 0.102 & 0.0048 & 0.063 & 0.0026 \\
\hline Lithium & $0.090^{*}$ & 0.0033 & $0.098^{*}$ & 0.0013 \\
\hline Magnesium & 0.225 & $0: 0061$ & 0.226 & 0.0039 \\
\hline Calcium & 0.263 & 0.0071 & 0.262 & 0.0034 \\
\hline Creatinine & 0.383 & 0.0114 & 0.380 & 0.0046 \\
\hline Creatine & $0.537^{*}$ & 0.0088 & $0.560^{*}$ & 0.0050 \\
\hline Zinc & $0.705^{*}$ & 0.0052 & $0.694^{*}$ & 0.0037 \\
\hline Lead & $0.575^{*}$ & 0.0150 & $0.888^{*}$ & 0.0046 \\
\hline Cadmium & 1.000 & - & 1.000 & - \\
\hline
\end{tabular}

$* n=4$ relationships between concentration $(\mathrm{X})$ of components and the zone length ratio $\mathrm{M} / \mathrm{Cs}(\mathrm{Y})$ obtained from isotachopherogramms are presented in table 3. The calibration plots shown in figures 4,5 and 6 for the six components were linear over a range of concentration up to $32 \mathrm{mmol} /$ for ammonium and creatinine, $80 \mathrm{mmol} / \mathrm{l}$ for sodium and potassium, 16 mmol/l for magnesium and $7.5 \mathrm{mmol} / \mathrm{l}$ for calcium with a sample volume of $1 \mu \mathrm{l}$. No mixed zones were observed throughout the whole concentration range studied.

Correlation coefficients ranged from 0.995 to 1.000 . Every calibration standard was determined in triplicate. The imprecision was very low. The coefficients of variation were $0.85 \%, 4.72 \%, 1.70 \%, 1.40 \%$, $1.77 \%$ and $1.36 \%$ for ammonium, sodium, potassium, magnesium, calcium and creatinine, respectively. 


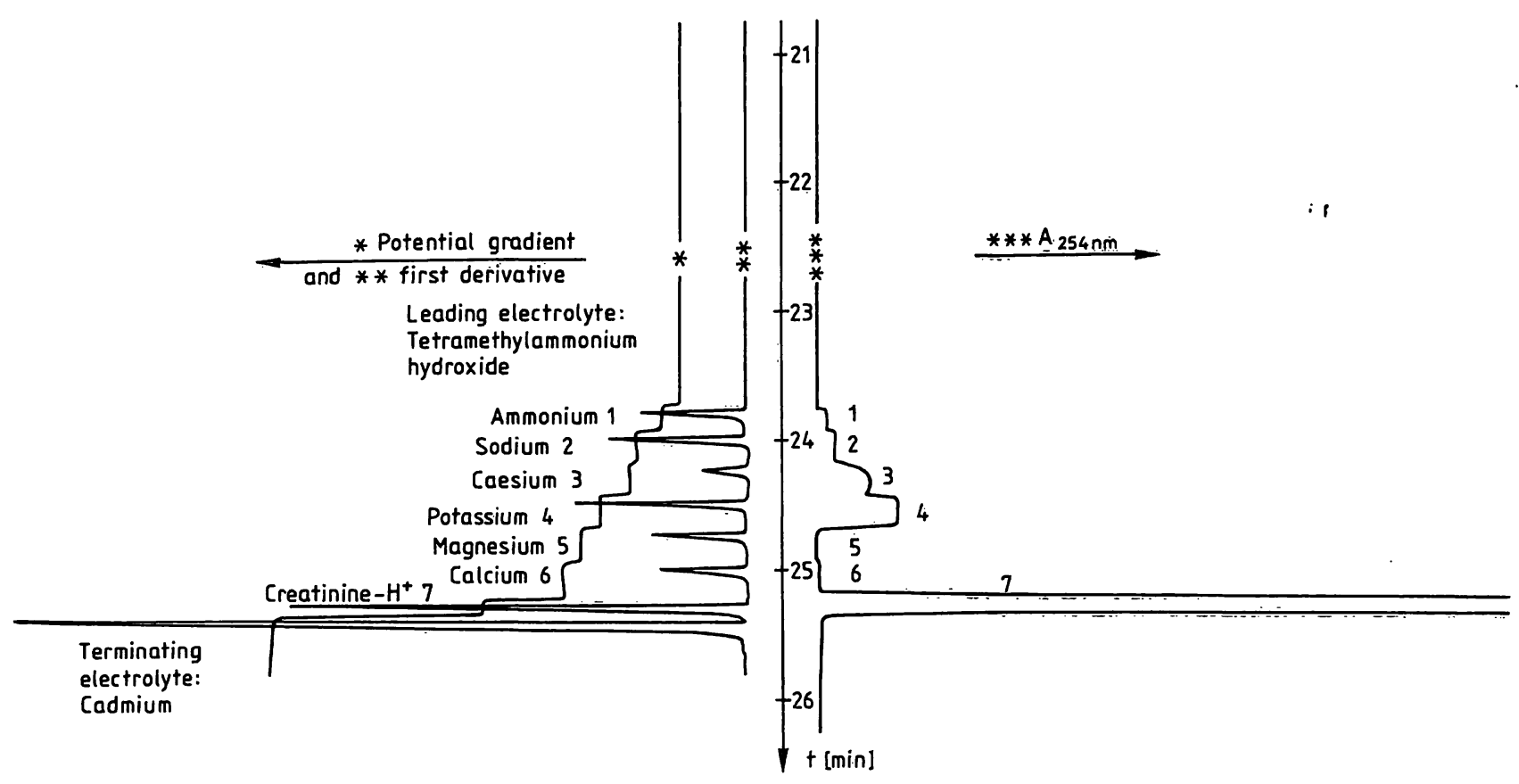

Fig. 2. Isotachopherogram with the same conditions as in figure 1. Electrolyte system $A$ was used.

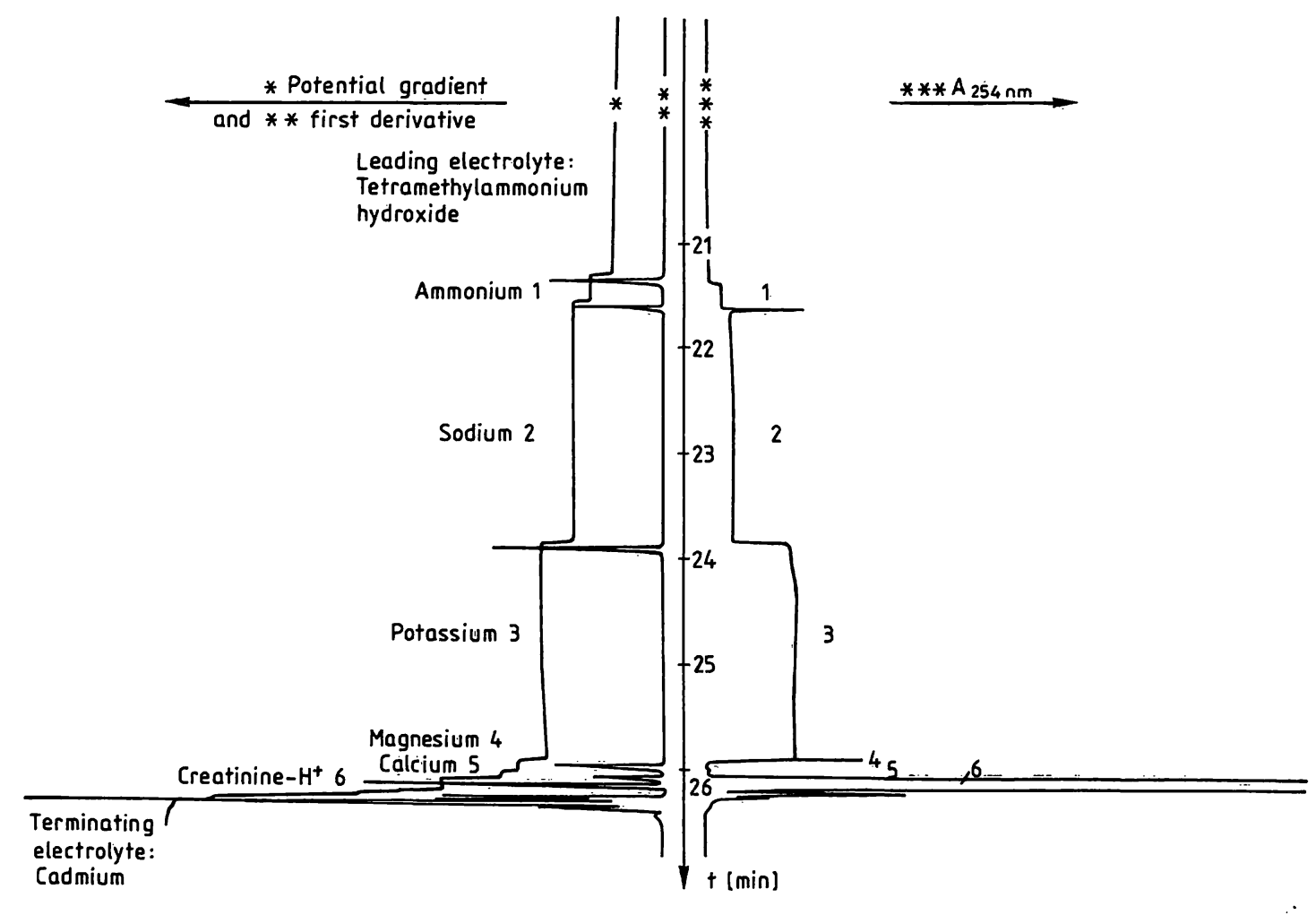

Fig. 3. Isotachopherogram of a pooled urine.

Volume injected: $1.0 \mu \mathrm{l}$

Components identified are indicated in figure 2. 
Tab. 3. Linearity of relation between zone length ratio, $M / C s$ $(y)$ and concentration $(x)$ in water or pooled urine

$M=$ zone length of cation

$\mathrm{r}=$ correlation coefficient

Cs $=$ zone length of caesium (internal standard)

\begin{tabular}{|c|c|c|}
\hline Cation & $\begin{array}{l}\text { Calibration curve } \\
\text { of standard solu- } \\
\text { tion }\end{array}$ & $\begin{array}{l}\text { Calibration curve } \\
\text { after standard addition } \\
\text { in pooled urine }\end{array}$ \\
\hline $\begin{array}{l}\text { Ammo- } \\
\text { nium }\end{array}$ & $\begin{array}{l}y=0.0242 x+0.0155 \\
r=1.000\end{array}$ & $\begin{array}{l}y=0.0256 x+0.3490 \\
r=1.000\end{array}$ \\
\hline Sodium & $\begin{array}{l}y=0.0285 x+0.0485 \\
r=0.998\end{array}$ & $\begin{array}{l}y=0.0261 x+3.290 \\
r=0.995\end{array}$ \\
\hline $\begin{array}{l}\text { Potas- } \\
\text { sium }\end{array}$ & $\begin{array}{l}y=0.0348 x+0.0345 \\
r=0.998\end{array}$ & $\begin{array}{l}y=0.0369 x+1.5160 \\
r=1.000\end{array}$ \\
\hline $\begin{array}{l}\text { Magne- } \\
\text { sium }\end{array}$ & $\begin{array}{l}y=0.0329 x+0.0097 \\
r=0.999\end{array}$ & $\begin{array}{l}y=0.0316 x+0.1165 \\
r=0.999\end{array}$ \\
\hline $\begin{array}{l}\text { Cal- } \\
\text { cium }\end{array}$ & $\begin{array}{l}y=0.0312 x+0.0124 \\
r=0.999\end{array}$ & $\begin{array}{l}y=0.0328 x+0.0786 \\
r=0.998\end{array}$ \\
\hline $\begin{array}{l}\text { Creati- } \\
\text { nine }\end{array}$ & $\begin{array}{l}y=0.0248 x-0.002 \\
r=1.000\end{array}$ & $\begin{array}{l}y=0.0254 x+0.003 \\
r=1.000\end{array}$ \\
\hline
\end{tabular}

\section{Precision and accuracy}

The within-day variation (CV) obtained by assaying three different pooled urine samples 12 times each in one run, ranged from $0.92-4.95 \%$.

The between-day variations for the same samples assayed once each in 6 different runs ranged from $1.00-7.41 \%$ (tab. 4). Different known amounts of creatinine and chloride salts of ammonium, sodium, potassium, magnesium and calcium, respectively, were added to a pooled urine sample. Data obtained are summarized in table 5. The mean deviation from $100 \%$ recovery of these components added to urine samples is $3.1 \%$.

\section{Method comparison}

The proposed method was directly compared with alternative routine methods. Figures 7 through 12 show the correlation between isotachophoretic determinations with routine methods. The corresponding techniques were an enzymatic method for ammonium (7), flame photometry for sodium and potassium (8), atomic absorption spectrometry for magnesium and calcium (9) and a colorimetric assay for creatinine (10). Isotachophoretic results were plotted against the results of the routine methods. The set of data were statistically evaluated by linear regression, calculation of correlation and by the procedure of Passing \& Bablok (11). The characteristics of the straight lines (slope, intercept) are well within the confidence limits for the methods. The results are summarized in table 6. The isotachophoretic method shows a good correlation with the routine methods.

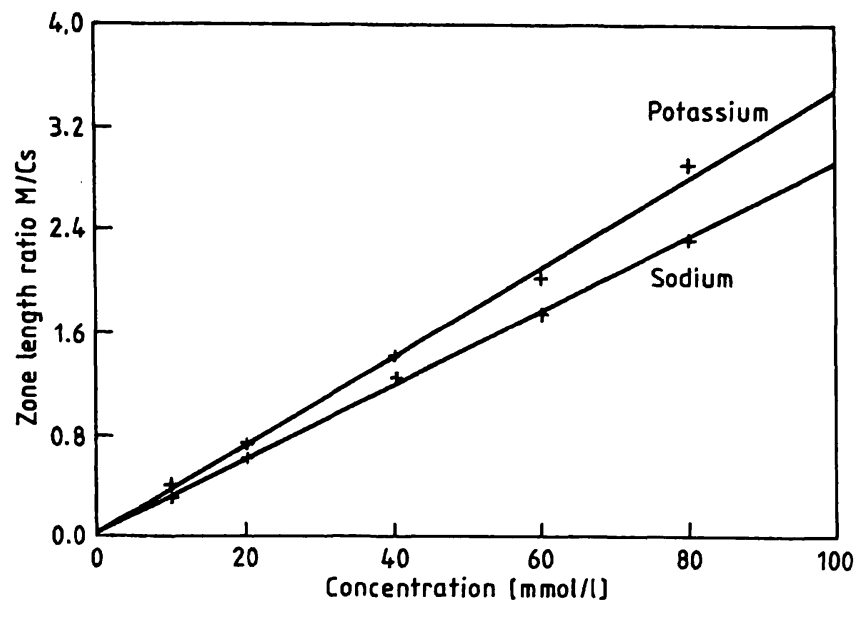

Fig. 4. Calibration curves for sodium and potassium standards. Zone length ratios $\mathrm{M} / \mathrm{Cs}$ are plotted against concentrations of sodium and potassium (mmol/l) $\mathrm{M}=$ Zone length of cation, $\mathrm{Cs}=$ Zone length of caesium

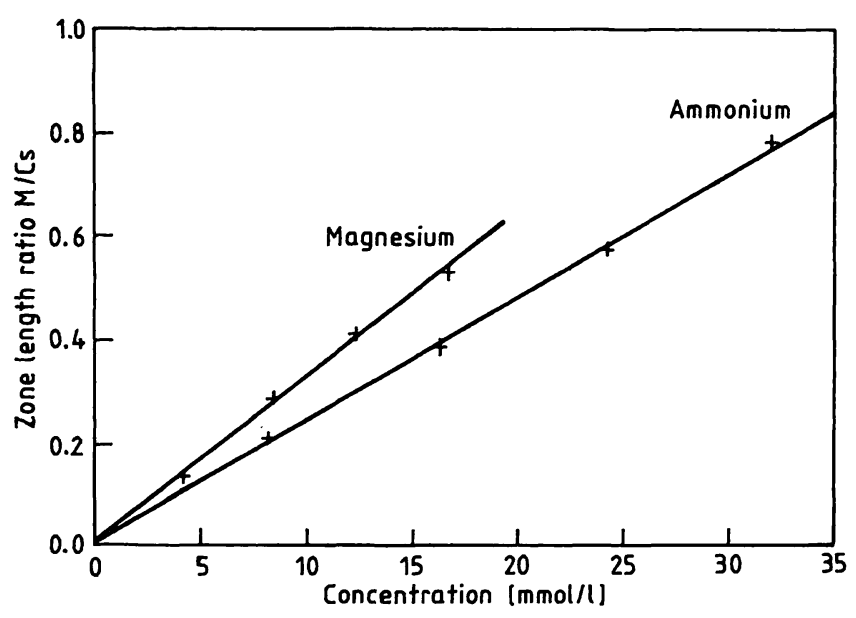

Fig. 5. Calibration curves for ammonium and magnesium standards.

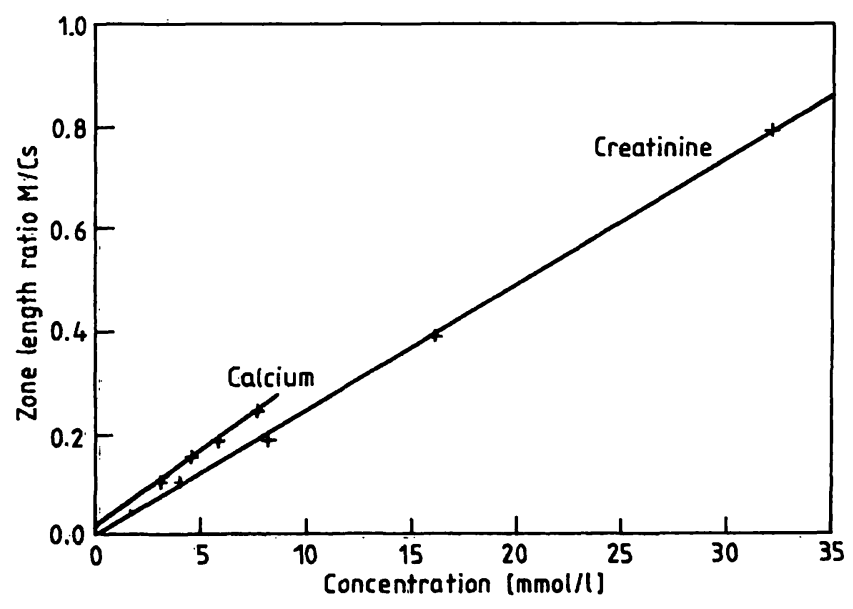

Fig. 6. Calibration curves for creatinine and calcium standards. 
Tab. 4. Precision of analysis of urinary cationic compounds

Results are mean \pm SD of determinations with three pooled urine samples. $1 \mu \mathrm{l}$ of the pooled urine samples after 3-fold dilution with internal standard solution $(1+2)$ were analysed repeatedly.

\begin{tabular}{|c|c|c|c|c|c|c|c|}
\hline \multirow{3}{*}{\multicolumn{2}{|c|}{$\begin{array}{l}\text { Cation } \\
\text { Ammonium }\end{array}$}} & \multicolumn{2}{|c|}{ Within-day $(n=12)$} & \multicolumn{4}{|c|}{ Between-day $(n=6)$} \\
\hline & & $c, \mathrm{mmol} / \mathrm{l}$ & \multirow{2}{*}{$\begin{array}{l}\mathrm{CV}, \% \\
1.76 \\
1.43 \\
1.41\end{array}$} & \multicolumn{3}{|c|}{$c, \mathrm{mmol} / \mathrm{l}$} & \multirow{2}{*}{$\begin{array}{l}\text { CV, \% } \\
7.41 \\
1.98 \\
5.43\end{array}$} \\
\hline & & $\begin{array}{l}15.3 \pm 0.27 \\
16.8 \pm 0.24 \\
14.9 \pm 0.21\end{array}$ & & $\begin{array}{l}14.7 \\
16.7 \\
15.1\end{array}$ & $\begin{array}{l} \pm 1.09 \\
\pm 0.33 \\
\pm 0.82\end{array}$ & $\therefore$ & \\
\hline Sodium & & $\begin{array}{c}90.8 \pm 1.15 \\
88.8 \pm 0.95 \\
202 \pm 5.55\end{array}$ & $\begin{array}{l}1.27 \\
1.07 \\
2.75\end{array}$ & $\begin{array}{c}91.3 \\
86.7 \\
204\end{array}$ & $\begin{array}{l} \pm 1.85 \\
\pm 0.87 \\
\pm 7.08\end{array}$ & & $\begin{array}{l}2.03 \\
1.00 \\
3.47\end{array}$ \\
\hline Potassium & & $\begin{array}{r}64.0 \pm 0.59 \\
34.6 \pm 0.26 \\
118 \quad \pm 4.23\end{array}$ & $\begin{array}{l}0.92 \\
0.75 \\
3.58\end{array}$ & $\begin{array}{c}64.4 \\
34.6 \\
120\end{array}$ & $\begin{array}{l} \pm 1.43 \\
\pm 0.55 \\
\pm 5.58\end{array}$ & & $\begin{array}{l}2.22 \\
1.59 \\
4.65\end{array}$ \\
\hline Magnesium & & $\begin{array}{r}3.49 \pm 0.14 \\
3.84 \pm 0.15 \\
14.6 \pm 0.18\end{array}$ & $\begin{array}{l}4.01 \\
3.91 \\
1.23\end{array}$ & $\begin{array}{c}3.57 \\
3.67 \\
14.8\end{array}$ & $\begin{array}{l} \pm 0.10 \\
\pm 0.10 \\
\pm 0.92\end{array}$ & & $\begin{array}{l}2.80 \\
2.72 \\
6.22\end{array}$ \\
\hline Calcium & & $\begin{array}{l}4.91 \pm 0.20 \\
3.95 \pm 0.14 \\
5.02 \pm 0.14\end{array}$ & $\begin{array}{l}4.07 \\
3.54 \\
2.79\end{array}$ & $\begin{array}{l}5.01 \\
3.91 \\
5.28\end{array}$ & $\begin{array}{l} \pm 0.19 \\
\pm 0.11 \\
\pm 0.20\end{array}$ & & $\begin{array}{l}3.79 \\
2.81 \\
3.79\end{array}$ \\
\hline Creatinine & $\therefore$ & $\begin{array}{l}5.91 \pm 0.20 \\
7.41 \pm 0.16 \\
21.4 \pm 1.06\end{array}$ & $\begin{array}{l}3.38 \\
2.24 \\
4.95\end{array}$ & $\begin{array}{r}5.48 \\
7.10 \\
22.4\end{array}$ & $\begin{array}{l} \pm 0.34 \\
\pm 0.33 \\
\pm 0.97\end{array}$ & & $\begin{array}{l}6.20 \\
4.65 \\
4.33\end{array}$ \\
\hline
\end{tabular}

Tab. 5. Analytical recovery of ammonium, sodium, potassium, magnesium, calcium and creatinine from pooled urine.

\begin{tabular}{|c|c|c|c|c|}
\hline Cation & $\begin{array}{l}\text { Added } \\
\mathrm{mmol} / \mathrm{l}\end{array}$ & $\begin{array}{l}\text { Measured } \\
\mathrm{mmol} / 1\end{array}$ & $\begin{array}{l}\text { Theoretical } \\
\text { mmol/1 }\end{array}$ & $\begin{array}{l}\text { Recovery } \\
\%\end{array}$ \\
\hline Ammonium & $\begin{array}{r}0 \\
3.00 \\
6.00 \\
9.00 \\
12.00\end{array}$ & $\begin{array}{l}12.39 \\
15.49 \\
18.59 \\
21.54 \\
24.57\end{array}$ & $\begin{array}{l}- \\
15.39 \\
18.39 \\
21.39 \\
24.39\end{array}$ & $\begin{array}{l}- \\
103 \\
103 \\
102 \\
102\end{array}$ \\
\hline Sodium & $\begin{array}{l}0 \\
15.0 \\
30.0 \\
45.0 \\
60.0\end{array}$ & $\begin{array}{l}109.2 \\
124.9 \\
139.3 \\
150.6 \\
164.9\end{array}$ & $\begin{array}{l}- \\
124.2 \\
139.2 \\
154.2 \\
169.2\end{array}$ & $\begin{array}{r}- \\
105 \\
100 \\
92 \\
93\end{array}$ \\
\hline Potassium & $\begin{array}{c}0 \\
15.0 \\
30.0 \\
45.0 \\
60.0\end{array}$ & $\begin{array}{r}42.5 \\
58.2 \\
72.5 \\
89.6 \\
104.4\end{array}$ & $\begin{array}{r}- \\
57.5 \\
72.5 \\
87.5 \\
102.5\end{array}$ & $\begin{array}{l}- \\
105 \\
100 \\
105 \\
103\end{array}$ \\
\hline Magnesium & $\begin{array}{l}0 \\
1.00 \\
2.00 \\
3.00 \\
4.00\end{array}$ & $\begin{array}{l}1.93 \\
3.00 \\
3.95 \\
4.91 \\
6.02\end{array}$ & $\begin{array}{r}- \\
2.93 \\
3.93 \\
4.93 \\
5.93\end{array}$ & $\begin{array}{r}- \\
107 \\
101 \\
99 \\
102\end{array}$ \\
\hline Calcium & $\begin{array}{l}0 \\
1.21 \\
2.42 \\
3.63 \\
4.83\end{array}$ & $\begin{array}{l}2.11 \\
3.45 \\
4.54 \\
6.10 \\
7.12\end{array}$ & $\begin{array}{r}- \\
3.32 \\
4.53 \\
5.74 \\
6.94\end{array}$ & $\begin{array}{l}- \\
111 \\
100 \\
110 \\
104\end{array}$ \\
\hline Creatinine & $\begin{array}{l}0 \\
2.00 \\
4.00 \\
6.00 \\
8.00\end{array}$ & $\begin{array}{r}7.89 \\
9.90 \\
11.99 \\
13.65 \\
16.12\end{array}$ & $\begin{array}{r}- \\
9.89 \\
11.89 \\
13.89 \\
15.89\end{array}$ & $\begin{array}{r}- \\
100 \\
102 \\
96 \\
103\end{array}$ \\
\hline
\end{tabular}

\section{Discussion}

Separation and quantification of six cationic species in aqueous solution or, especially in human urine, presents a formidable problem. Alkali and alkaline earth ions are chemically rather inert or undergo reactions which are not very specific. Physical methods like atomic emission or atomic absorption photometry are therefore used routinely to determine their concentration. For the electrophoretic separation according to effective ionic mobilities conditions had to be found that alter the relative mobilities in aqueous solution to afford practically measurable differences. Although very small differences in potential gradient can in principle be detected, a rather long analysis time is required for the separation of mixed zones. Also, a leading electrolyte had to be found which moves faster than any of the ions to be determined by the procedure. Tetramethylammonium in methanolic solution was finally adopted as the solution to this problem. However, the effective mobilities of ammonium and potassium were very close to one another. Using Triton X-100 as a non-ionic complexforming agent, the appropriate changes in ionic mobilities were established. From the UV-absorbance we conclude that complex formation increases in the order ammonium, sodium, caesium, potassium. One of the many advantages of the isotachophoretic method is the high degree of freedom offered by a great number of parameters that can independently be cho- 


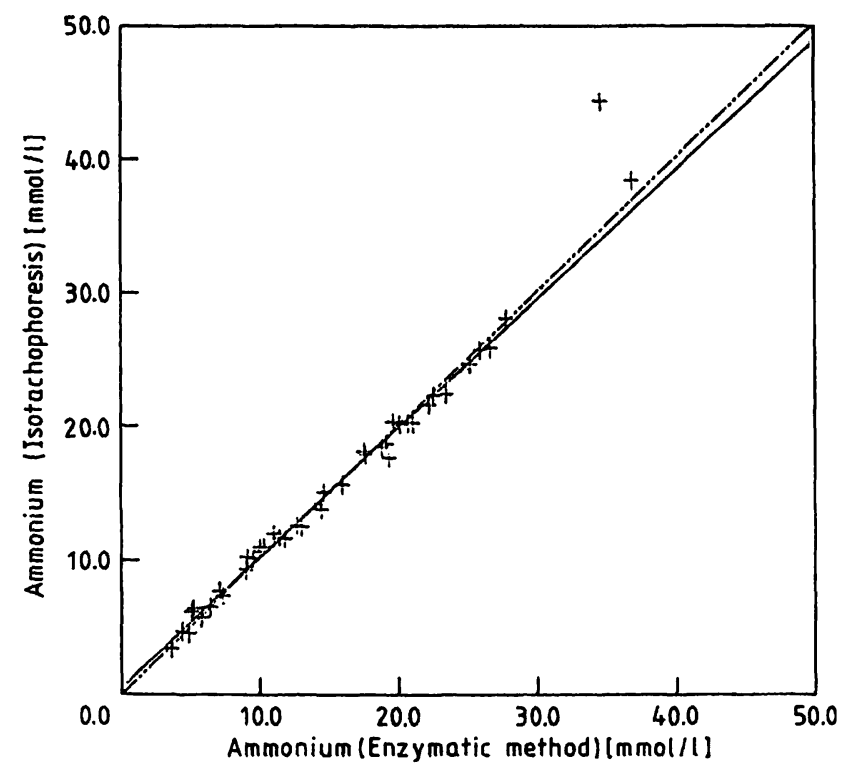

Fig. 7. Correlation between present method and enzymatic method for determination of ammonium in 43 urine samples.

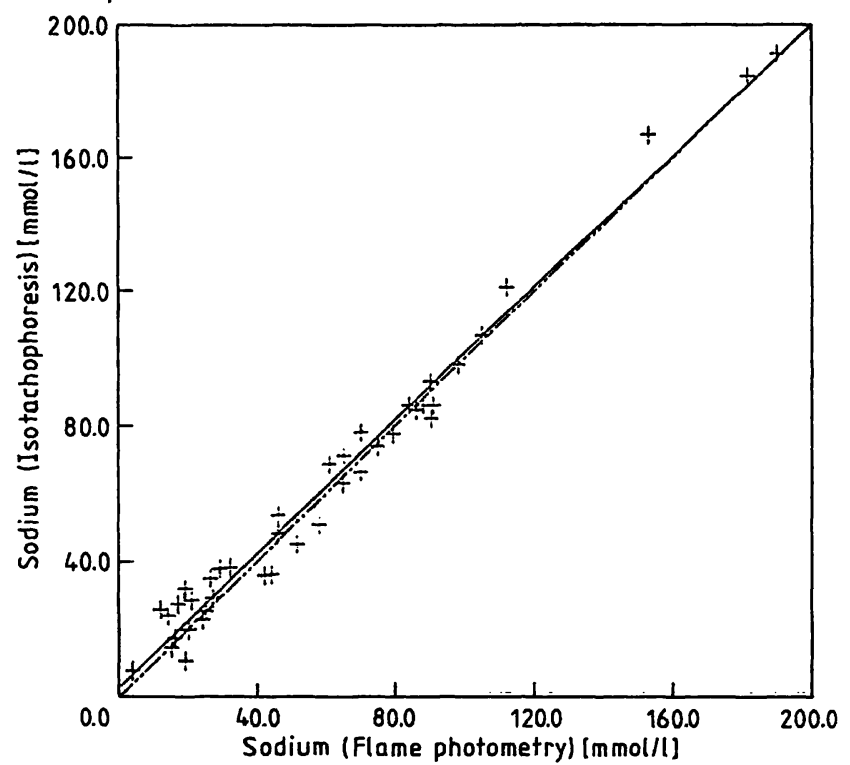

Fig. 8. Correlation between present method and flame photometry for determination of sodium in $\mathbf{4 2}$ urine samples.

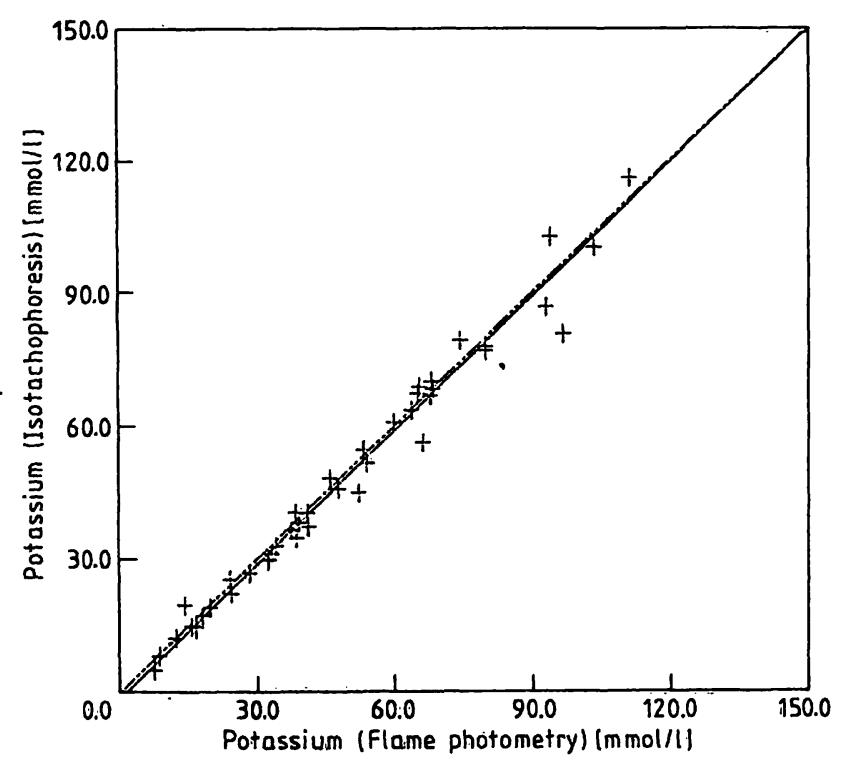

Fig. 9. Correlation between present method and flame photometry for determination of potassium in 42 urine samples.

J. Clin. Chem. Clin. Biochem. / Vol. 26, 1988 / No. 2

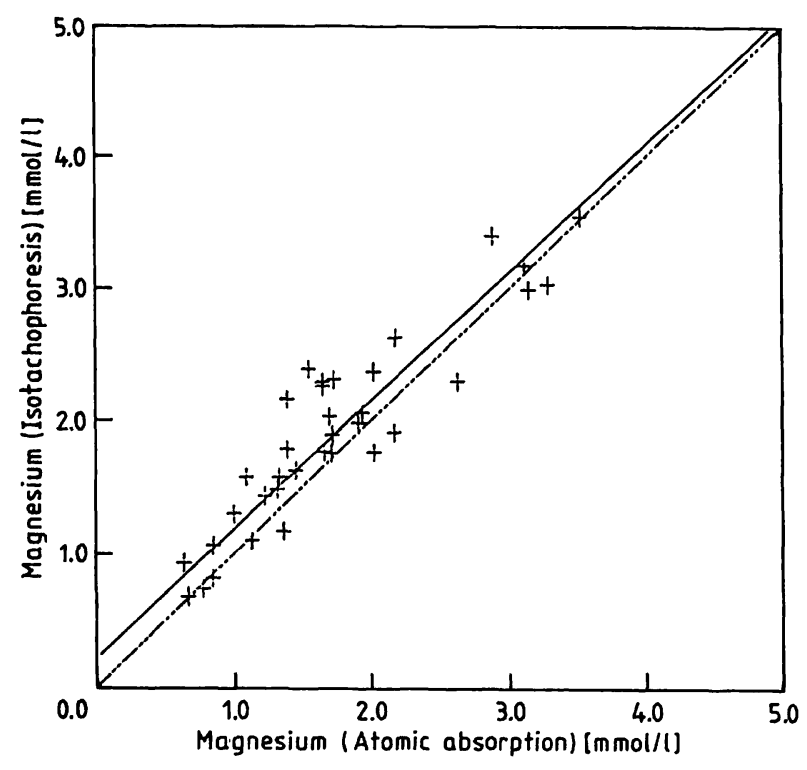

Fig. 10. Correlation between present method and atomic absorption spectrometry for determination of magnesium in 37 urine samples.

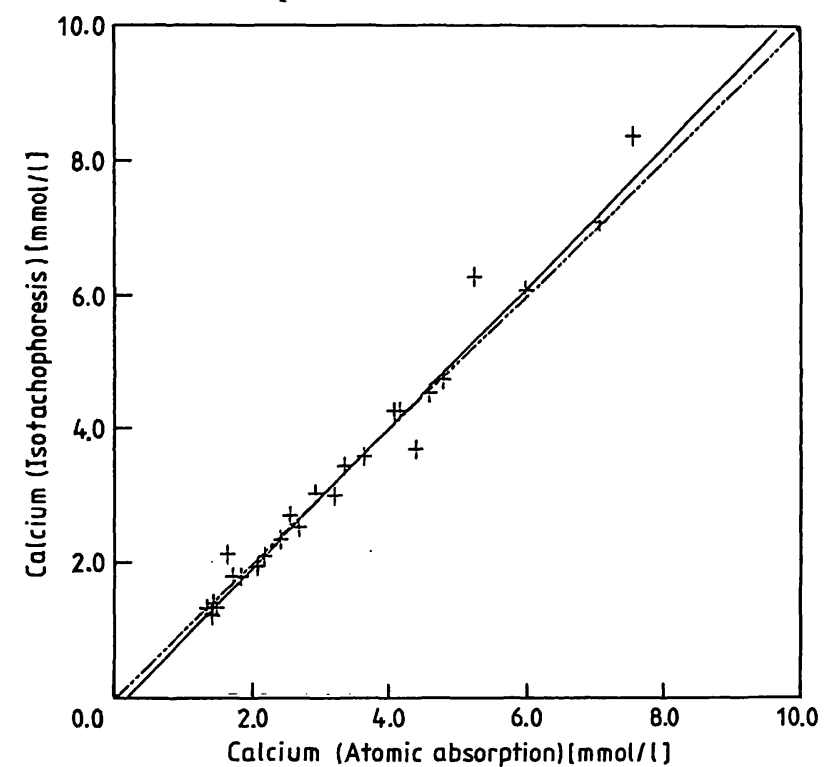

Fig. 11. Correlation between present method and atomic absorption spectrometry for determination of calcium in 26 urine samples.

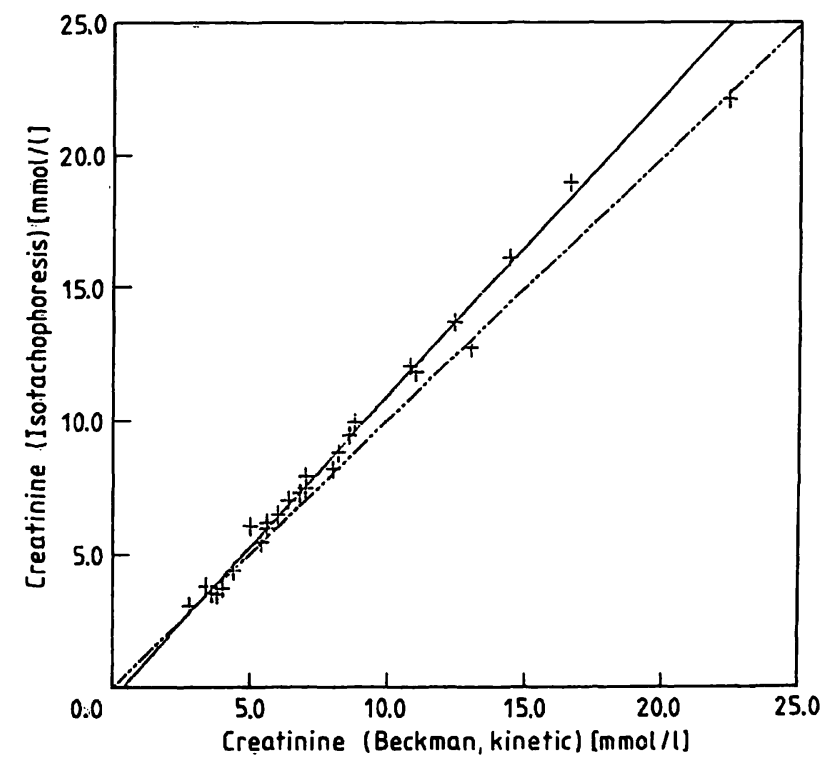

Fig. 12. Correlation between present method and colorimetric method for determination of creatinine in 26 urine samples. 
Tab. 6. Comparison of methods

$r=$ correlation coefficient $b=$ slope $a=$ intercept $(\mathrm{mmol} / \mathrm{l})$

\begin{tabular}{|c|c|c|c|c|c|c|}
\hline Cation & $\mathbf{n}$ & $\overline{\mathbf{x}}$ & $\bar{y}$ & $\mathrm{r}$ & a & b \\
\hline $\begin{array}{l}\text { Ammonium }(\mathrm{mmol} / \mathrm{l}) \\
\mathrm{y}=\text { Isotachophoresis } \\
\mathrm{x}=\text { Enzymatic method }\end{array}$ & 43 & 15.217 & 15.442 & 0.984 & $\begin{array}{r}-0.685 \\
\quad \text {, }\end{array}$ & 1.060 \\
\hline $\begin{array}{l}\text { Sodium (mmol/l) } \\
\mathrm{y}=\text { Isotachophoresis } \\
\mathrm{x}=\text { Flame photometry }\end{array}$ & 42 & 59.819 & 62.941 & 0.989 & +2.144 & $1: 000$ \\
\hline $\begin{array}{l}\text { Potassium (mmol/l) } \\
\mathrm{y}=\text { Isotachophoresis } \\
\mathrm{x}=\text { Flame photometry }\end{array}$ & 42 & 48.900 & 47.992 & 0.992 & -1.252 & 1.002 \\
\hline $\begin{array}{l}\text { Magnesium (mmol/l) } \\
\mathrm{y}=\text { Isotachophoresis } \\
\mathrm{x}=\text { Atomic absorption }\end{array}$ & 37 & 2.017 & 2.178 & 0.985 & +0.354 & 0.905 \\
\hline $\begin{array}{l}\text { Calcium (mmol/l) } \\
\mathrm{y}=\text { Isotachophoresis } \\
\mathrm{x}=\text { Atomic absorption }\end{array}$ & 16 & 3.672 & 3.794 & 0.984 & -0.126 & 1.068 \\
\hline $\begin{array}{l}\text { Creatinine (mmol/l) } \\
\mathrm{y}=\text { Isotachophoresis } \\
\mathrm{x}=\text { Jaffe reaction, } \\
\quad \text { kinetic }\end{array}$ & 26 & 8.115 & 8.654 & 0.992 & +0.018 & 1.065 \\
\hline
\end{tabular}

sen. These include the type, concentration and $\mathrm{pH}$ of leading and terminating electrolyte, the solvent, the diameter and length of the capillary, the current, the complexing agents (non-ionic or anionic). It is therefore almost always possible to find suitable conditions for a certain problem. The zone length for a given concentration of one ionic species depends only on the diameter of the capillary in the detector (which is constant) and the concentration of the leading electrolyte. Highly reproducible results can therefore be obtained. Imprecision due to the variation of the injected volume can be eliminated using an internal standard.

This standard, or a second standard, can also be used to avoid errors in determining the volume of the 24hour urine collections. Ronquist (12) proposed the addition of a constant, determined volume of $\mathrm{LiCl}$ of constant concentration to the empty collecting container. The final concentration of lithium, as determined, for example, by isotachophoresis would then also permit calculation of the total 24-hour volume.

Lithium is an alkali metal ion which appears only occasionally in the urine of patients on lithium therapy. It can easily be detected between sodium and magnesium using System B (tab. 1 and tab. 2). In System A, however, the effective mobilities of lithium and sodium are rather close to one another (tab. 1 and tab. 2). The presence of lithium is indicated by the appearance of a small peak in the first derivative of the potential gradient over time curve.

The only cation that cannot be measured in the untreated urine is the calcium ion. Due to the presence of a number of complexing anions like sulphate, phosphate and oxalate the amount of calcium in native urine is always underestimated by the isotachophoretic method. In addition, the amount of "free" calcium varies considerably with the concentration of these anions. If calcium is to be determined, the interfering anions must first be eliminated. We found that precipitation of these anions by lead ions, which have a lower mobility than creatinine (tab. 2), is suitable for this purpose.

The main disadvantage of isotachophoresis is the time of analysis, which is comparable with that of chromatographic procedures. It is hoped that further development of the method and construction of more sophisticated equipment with multielectrode arrays as described by Schuhmacher (13) will finally increase the practicability of this procedure.

\section{Acknowledgement}

We would like to thank Prof. E. Schumacher, Bern, for helpful discussions. 


\section{References}

1. Hesse, A. \& Vahlensieck, W. (1983) Normal values in $24 \mathrm{~h}$ urine for the diagnosis of metabolic errors in urolithiasis. Abstract Volume 5th European Congress of Clinical Chemistry, Budapest, Hungary, 250.

2. Eastham, R. D. (1985) Biochemical values in clinical medicine. Seventh edition. Bristol: John Wright \& Sons Ltd.

3. Dubowski, K. M. (1970) Specific ion activity determination for measurement of serum and urine electrolytes in renal disease. In: Laboratory Diagnosis of Kidney Diseases (Sunderman, F. W., ed.) pp. $271-277$.

4. Hirst, A. D. \& Howorth, P. J. N. (1975) Ann. Clin. Biochem. 12, 25-31.

5. Pei, P. \& Vonderschmitt, D. J. (1987) J. Clin. Chem. Clin. Biochem. 24, 253-259.

6. De Jong, P. \& Burggraaf, M. (1983) Clin. Chim. Acta 132, $63-71$

7. Sigma Chemical Co., St. Louis, MO, USA (1984) Sigma Diagnostics, Applications for Cobas Bio Centrifugal Analyzer Procedure No. 170-UV.

8. Berry, J. W., Chappell, D. G. \& Barnes, R. B. (1946) Ind. Eng. Chem. Anal. Ed. 18, 19-24.
9. Trudeau, D. L. \& Freier, E. F. (1967) Clin. Chem. 13, 101 114.

10. Flores, O. R. The Creatinine Analyzer 2 in Pediatric Applications. Beckman Creatinine Analyzer, Application Data Sheet CAD-2.

11. Passing, H. \& Bablok, W. (1983) a) J. Clin. Chem. Clin. Biochem. 21, 709-720. b) J. Clin. Chem. Clin. Biochem. $22,431-445$.

12. Ronquist, G., Andersson, G. \& Alin, Y. (1985) Clin. Chem. 31,1413-1414. Letter.

13. Schumacher, E., Thormann, W. \& Arn, D. (1981) A new approach to automated isotachophoresis with multichannel zone detection. Analytical chemistry symposia series. 6 , $33-39$.

14. Beckers, J. L. \& Everaerts, F. M. (1970) J. Chromatogr. $51,339-342$.

15. Everaerts, F. M., Becker, J. L. \& Verheggen, Th. P. E. M. (1976) Isotachophoresis (Theory, Instrumentation and Applications) J. Chromatogr. Library 6, 364-374.

16. Bocek, P. \& Foret, F. (1984) J. Chromatogr. 313, 189222.
P. Pei

Institut für Klinische Chemie

Universitätsspital

CH-8091 Zürich 
. 